\title{
Service Learning as Critical Pedagogy: Implications for Student Community Awareness and Citizenship Development
}

\author{
Hamdan Said \\ Universiti Teknologi Malaysia \\ p-hamdan@utm.my \\ Iqbal Ahmad \\ Universiti Teknologi Malaysia \\ shahnavi777@hotmail.com \\ Zainudin Hassan \\ Universiti Teknologi Malaysia \\ p-zainudin@utm.my \\ Zubaidah Awang \\ Universiti Teknologi Malaysia \\ m-zu@utm.my
}

Doi:10.5901/mjss.2015.v6n2p471

\begin{abstract}
As an innovative learning approach, service-learning possesses the potential to enhance community awareness of students and their citizenship growth. Through community awareness students understand their roles and responsibility as active citizens. Research has discovered that as critical pedagogy service-learning still lacks the ability to claim for developing real community awareness among students. This paper had two aims: first to evaluate the claim of service-learning on students' community awareness development and second, to assess the ability of service-learning to promote students' citizenship development. For this purpose, this paper investigated into the current literature on how service-learning provides real community based learning opportunities to the students in order to achieve these goals. Exploration of the existing literature revealed that despite of being termed as a time-consuming and expensive practice, service-learning has the potential to develop citizenship propensities of students as well as creation of community awareness. The review revealed that servicelearning achieves these two goals on the basis of its characteristic of reciprocity. The paper concludes that as a critical pedagogy service-learning plays an important role in developing students' community awareness and citizenship development.
\end{abstract}

Keywords: service-learning critical pedagogy, community awareness, citizenship development

\section{Introduction}

Service-learning is an important educational method that develops students' knowledge and skills to become contributing and useful citizens (Arenas, Bosworth, \& Kwandayi, 2006; Giles \& Eyler, 1994). In the last decade, a major shift has occurred in the practice of service-learning changing from community service to student learning (Arman \& Scherer, 2002; Bringle \& Hatcher, 2009). So the main aim of service-learning is now less service more learning (Howard, 1998; Ryan, 2012). Since its inception, one of the major aims of service-learning has been community engagement. In early 1970s, community development was considered to be the main goal of service-learning (Eyler \& Giles, 1999). In late 90s, the trend in service-learning has shifted from the academic and non-academic role of service-learning to volunteerism in different parts of the world (Strupeck \& Whitten, 2004). In the last two decades, the trend in service-learning has shifted again from mere volunteerism to more comprehensive approach, that is, learning and development of students in the community setting (Brown, 2001; Govekar \& Rishi, 2007).

Nowadays, service-learning is considered as a critical pedagogy that is uniquely positioned to achieve more than one goal. For example, it develops students' community exposure, civic development and career growth, social 
development as well as development of communities as equally important stakeholders (Burnett, Long, \& Horne, 2005; Lawrence \& Butler, 2010; Markus, Howard, \& King, 1993; Zimmerman \& Cleary, 2006). More recently researchers seem unanimously agreed on reciprocity as one of the important characteristics of service-learning (Butin, 2006; KenworthyU'Ren \& Peterson, 2005). Reciprocity implies that as a critical pedagogy, on one hand, service-learning prepares students for their academic course and on the other hand, it provides service to the community (Vogelgesang \& Astin, 2000). Many researchers have also endorsed this ability of service-learning. Even they have gone to the extent of saying that when conceptualized in this way service-learning is a pedagogical model that intentionally integrates academic learning and community service (Baggerly, 2006; Kezar \& Rhoads, 2001). Many studies have indicated that servicelearning not only develops civic propensities, but it also strengthens students' academic learning and enhances their higher thinking skills such as critical thinking and problem solving (Eyler, 2002; Howard, 2003; Markus, et al., 1993).

Writers have concluded that service-learning benefits all stakeholders such as community, students, teachers and organizations equally (Gottlieb \& Robinson, 2006; Markus, et al., 1993). Recently, some writers have indicated that despite the popularity of service-learning as an effective critical pedagogy, it is not clear how service-learning helps students develop community sense and community awareness (Dale \& Drake, 2005; King, 2004). Despite the claims to achieve some of the sublime aims of education such as development of active and responsible citizens, preparing leaders for future and preparing effective contributing society members, service based learning it is less clear how service-learning achieves these goals. There are mixed results and some apprehensions that service-learning lacks the potential towards development of citizenship skills of students. Even very few studies have explored the community development aspect of service-learning which is equally important as student development. However, current research does not provide enough clarifications for this gap (Baggerly, 2006; Bringle \& Steinberg, 2010; Kaye, 2004). However, in spite of this, there are some evidences that service-learning offers wider opportunities to society, young people and organizations alike. But this area has been less explored (Bringle \& Hatcher, 1996; Zimmerman \& Cleary, 2006).

The main purpose of this paper is to investigate into the gap that how service-learning contributes towards community development and citizenship skills enhancement of students. This area has been overlooked in the current literature. This paper presents many clarifications which will be helpful to clearly understand the contributions of servicelearning as a tool in community and citizenship development awareness. The study supports previous findings and provides some more stronger theoretical foundations for implementation of service-learning as a useful pedagogy for promoting community awareness and citizenship development of students in different fields.

\section{Methodology}

This paper adopts critical review as a method of investigation to explore the existing literature on service-learning for seeking answers to the few questions of this research. Critical review as a method of investigation is helpful in exploring the deeper dimensions of concepts and practices. In this regard, the paper attempts to review the role of service-learning as a critical pedagogy in developing students' community awareness. Second, by scanning the current literature, the paper also wants to ascertain the claim of service-learning that how students and communities collectively reap the benefits of service-learning in the form of service-delivery and how students find the opportunity to develop their citizenship knowledge and propensities as active citizens. The paper extents the body of knowledge in service-learning and also provides some new insights to researchers in the field of service-learning about its multidimensional role as an experiential pedagogy.

\section{Service-learning as Critical Pedagogy}

Service-learning is an important educational method that ensures the development of students in many ways (Furco, 1996; Kaye, 2004; Lane, 2008). As an educational experience, it provides students ample opportunities to actively participate in an organized service-activity to satisfy an identified human and community need (Chickering \& Braskamp, 2009). During the process of service delivery, students reflect and reciprocate on the community service (Keen \& Hall, 2009; Schwartzman, 2007). This reciprocation develops their understanding of course content, broader their appreciation of the discipline and enhances their sense of civic responsibility (Cone, 1996; Saltmarsh, 1996). Research has confirmed that service-learning effectively connects service in the community with classroom learning. In this way, students find wider hands-on real life experiences to apply their newly learned knowledge and skills in the community context (Bringle \& Hatcher, 1995; Speck \& Hoppe, 2004). To identify community needs and develop mechanisms to solve the community related problems is the sole ability of service-learning, because, service-learning combines service objectives with students' learning objectives (Sax, 2004; Wells \& Grabert, 2004). 
Actually the process of service-learning is characterized by reflection, discovery and acquisition of skills and knowledge through experience rather than rhetoric. This characteristic of service-learning makes it a distinct educational approach (Reinke, 2003). The process of doing reflection and acquisition of new skills becomes possible when students get practically involved in service-learning activities in the community setting (Yorio \& Ye, 2011). In this way, students have ample opportunities to develop collaborative and empowering relationships with their communities (Battistoni, 2002; Maybach, 1996). As a critical pedagogy, service-learning provides many benefits to students and communities alike such as civic development, professional skills enhancement and personal growth as well as solution of problems of communities (Cruz \& Giles, 2000; Hondagneu-Sotelo \& Raskoff, 1994). Research has established that the benefits of service-learning are not limited to students or communities only. It also benefits schools, colleges and universities in mitigating community needs, responding to community needs and indentifying employer needs (Desmond \& Stahl, 2011; Diambra, McClam, Fuss, Burton, \& Fudge, 2009).

\section{Students' Community Awareness}

Research has widely recognized the role of service-learning as a critical pedagogy (Egger, 2008). In the two last decades, research indicated that as a community based teaching and learning experience, service-learning creates effective connections between community and students' academic development (Furco \& Root, 2010; Metcalf, 2010; Morgan \& Streb, 2001). Through community exposure students widely learn about the problems and issues in the society, develop stronger sense of civic responsibility and provide service to the communities to solve their problems (Fiske, 2002; Markus, et al., 1993; Pritchard \& Whitehead, 2004). Others stated that service-learning is a way for students to demonstrate their knowledge, skills, critical thinking and judgment in real world situation to meet the varying social needs of the communities in which they live (Astin \& Sax, 1998; Ethridge \& Branscomb, 2009).

Actually service-learning differs both from volunteerism, charity and community service. It is an experiential learning approach which is based on learning as its main purpose rather than service (Zaff \& Lerner, 2010; Zlotkowski, 1995). However, it is unique because it provides benefits both to the community that receives the service and the students who perform the service (Engberg \& Fox, 2011). By nature it is collaborative and interactive. Thus the focus of service-learning is to promote both academic knowledge and civic skills of students. For this purpose, students go to the community side, where they apply their skills in real life situations to solve community problems (Giles \& Eyler, 1994; Lemieux \& Allen, 2007). Students' practical interaction and experiences with community members and organizational representatives develop their citizenship skills such as communication, problem solving, interpersonal and leadership (Furco \& Billig, 2002; Speck, 2001).

Service-learning has been defined by different people differently. There is no unanimity among scholars on one definition as it takes different forms under different conditions (Myers-Lipton, 1996). Writers have termed service-learning as a strategy, programme, philosophy and pedagogy and so on (Moore, 2000). Other writers say that as a critical pedagogy it effectively achieves two goals of education: promotion of civic development of students and their community awareness. As a strategy, service-learning develops skills of students with the help of which they solve problems in the community and strengthen their connections with others such as community organizations and groups (Fenzel \& Peyrot, 2005; Ramaley, 2000; Sedlak, Doheny, Panthofer, \& Anaya, 2003; Strupeck \& Whitten, 2004). As an active pedagogy, service-learning connects community service-learning with students' academic course objectives (Wells \& Grabert, 2004).

In another study researchers have pointed out that although service-learning is an effective teaching and learning tool to develop students' community interaction abilities, yet, it is an expensive exercise and cannot be conducted in every context (Rama, Ravenscroft, Wolcott, \& Zlotkowski, 2000). Due to this reason, some of the service-learning projects are highly structured and long term planning and many human and physical resources are required to conduct it effectively in some places where there is dearth of such resources (Govekar \& Rishi, 2007; Teranishi, 2007). Servicelearning as an educational method combines service objectives with learning objectives. The main intent is to benefit both the service provider (student) and the receiver (community) (Parker \& Altman Dautoff, 2007; Terkla, O'Leary, Wilson, \& Diaz, 2007). One of the prominent benefits of service-learning is that the service experience enriches students' learning, develops their civic responsibility, sense of collaboration and acquisition of new skills and knowledge (Bringle \& Steinberg, 2010; Gelmon, 2001). Despite the variety of service-learning activities, all types of service-learning have the following four main components in common: (1) credit bearing, (2) community service, (3) structured reflection, (4) collaboration and reciprocity (Rama, et al., 2000).

Service-learning is a credit bearing teaching and learning pedagogy in which students take part in an organized service activity in a community setting to satisfy some community needs (Bringle \& Hatcher, 1995). This interaction promotes their civic development and community related knowledge (Waldstein \& Reiher, 2001). Students critically think 
on their service activity that helps in deeper understanding of not only the course content but also helps in developing sense of civic responsibility among them. Despite of the many benefits, one of the misunderstandings about servicelearning is that it has been taken as community service, volunteerism or philanthropy (Giles \& Eyler, 1994). These writers further explain that in volunteer work, community service or philanthropist activity, volunteers offer their services free of charge to the recipients or target community. The main purpose is social service not learning. However, in servicelearning, the main focus is on learning rather than on service (Parker \& Altman Dautoff, 2007; Simons \& Cleary, 2006).

In spite of the many promises that service-learning offers, studies have found mixed results (Tucker, McCarthy, Hoxmeier, \& Lenk, 1998). A recent study found that design, implementation and sustainability of service-learning. is going to be a big issue in the future because of the inadequate beneficiary involvement, lack of training, lack of finance, pedagogical concerns, institutional and physical concerns, lack of assessment and negative attitude towards servicelearning (Bringle \& Steinberg, 2010). For example, research has indicated that mixing community service with students' learning is not encouraging. In view of some researchers, service-learning is time and resources wasting because it actually promotes a communitarian anti-individualistic social agenda (Egger, 2008), According to others, physical setting is a potential barrier to service-learning effectiveness (Schwartzman, 2007). Similar issues were identified by others in a research study related to authentic assessment in service-learning (Butin, 2006). Butin (2006) further found that in service-learning the process of assessment is very complicated due to absence of well articulated criteria. In this regard, some writers have found that certain assessment mechanisms are missing to evaluate the outcomes related to participation in service-learning (McClam, Diambra, Burton, Fuss, \& Fudge, 2008). There is no assessment of many service-projects either because teachers have less know-how of how to assess or they have to wait until the servicelearning activity or project is completed (Speck \& Hoppe, 2004). It is thus time consuming and the academic session is over by that time (Arenas, et al., 2006; Simons \& Cleary, 2006).

On the other hand, other researchers have advocated that participation in service-learning enhances students' civic skills and their community commitment by developing them to be valuable citizens (Morgan \& Streb, 2001; Saltmarsh, 2005). Moreover some of the writers argue that service-learning is useful in many respects (Einfeld \& Collins, 2008). It has academic, moral and social benefits attached to it. Some others have declared that service learning is beneficial community based pedagogy (Kielsmeier, Scales, Roehlkepartain, \& Neal, 2004). These writers further elaborate that many social, moral, ethical and political issues of modern education could be solved today with the help of effective service-learning programmes (Bazemore \& Stinchcomb, 2004; Lawrence \& Butler, 2010).

Research has consistently reported that service-learning promotes students' interpersonal skills, community connection, career development and problem solving skills (Hondagneu-Sotelo \& Raskoff, 1994; Ottenritter, 2004; Root, Callahan, \& Sepanski, 2002; Zaff \& Lerner, 2010). Researchers have argued that those students who participate in service-learning can perform personal and civic responsibilities more effectively as compared those students who are enrolled in non-service-leaning courses (Skinner \& Chapman, 1999; Vogelgesang \& Astin, 2000). It is a powerful pedagogy to promote students' civic development through community exposure. In community setting, students find wider opportunities to learn beyond the bounds of the traditional classroom through interaction with community members and organizations (Lemieux \& Allen, 2007). Students in the service-learning learners outperform the non-service learners. The same study found that service-learning students achieved higher grades in mid-term and final exams (Simons \& Cleary, 2006). In another longitudinal study, involving 22,236 undergraduate students from 177 educational institutions, researchers found that students in service-learners obtained high grade point average as compared to the non-service learners (Vogelgesang \& Astin, 2000).

Scholars have also reported that service-learning increased confidence, patience, tolerance and improved leadership skills among students of different socio-economic backgrounds in different communities (Wade \& Yarbrough, 2005). Moreover in a phenomenological study of high school students it was discovered that after their participation in service-learning project, a remarkable positive change took place in community related attitudes of students (Brown, 2001). The study further revealed that students developed empathy and also demonstrated their intentions for volunteerism in the community. Another research found that those students who participated in a service-learning projects recognized their community related roles as active citizens (Diambra, et al., 2009).

\section{Students' Citizenship Development}

Basically service-learning is a civic engaging learning. Most of the studies for the last two decades have confirmed that service-learning has positive effects on students' civic attitudes and citizenship skills (Bringle \& Hatcher, 1995; Howard, 1998; Redman \& Clark, 2002). Those students who participate in service-learning activities have been seen to demonstrate better civic responsibility than those who did not take part in the service programmes (Moore, 2000). 
Students develop caring and responsible attitudes toward community needs and their own duties as responsible members of their societies. They try to solve problems of the communities in which they live (Deans, 1999; Ottenritter, 2004). Studies have also reported that service-learning increases student' community sense and problem solving skills. In this way, they work to solve different community problems in collaboration with others (Seifer, 1998). As an academic pedagogy, service-learning has been found to promote students' educational interests by developing their engaged attitudes (Arman \& Scherer, 2002; Pritchard \& Whitehead, 2004).

Other studies have indicated that students who participate in service-learning programmes also develop life skills such as effective communication, leadership, problem-solving and critical thinking. These skills are considered essential employability skills in the present job competitive market (Hager, Holland, \& Beckett, 2002). Community is one of the essential elements in the service-learning process. Through service-learning activities, students identify the pressing needs and problems of the communities and try to mitigate them through building positive partnerships with schools and communities (Quezada \& Christopherson, 2005). In this way, communities see the youth as essential resource. This partnership gives impetus to the belief on the part of community members that the new generation is caring, active and committed (Rama, et al., 2000).

Literature informs that schools are not the centres only to provide young people with knowledge about how to live a community life, but it is also the responsibility of schools to provide them with the experience to know and practice citizenship (Kahne, Westheimer, \& Rogers, 2000; Root, et al., 2002). For this purpose, community based organizations can also provide a more practical learning environment to the students than the traditional classrooms for their educational development (Ramaley, 2000). In view of scholars, learning in the community setting is more natural, open, critical and reciprocal than the closed boundaries of a traditional classrooms where teachers tells about community life and citizenship (Brandell \& Hinck, 1997). On the other hand, in service-learning programmes, students do and learn how to become citizens and how to help community people to solve their problems (Quezada \& Christopherson, 2005; Steinberg, Hatcher, \& Bringle, 2011). Research has strongly supported the theory of Dewey that students develop better learning skills and knowledge through personal explorations and experience and as an experiential educational practice, service-learning best achieves the community development and citizenship development goals of education (Cone, 1996; Prentice, 2011). Many other scholars have also argued that learning is a constructive process. Individuals basically reconstruct their new gained knowledge through new experiences and interactions (Bandura \& Adams, 1977; Cole, JohnSteiner, Scribner, \& Souberman, 1978; Kolb, 1984). Service-learning being an experiential learning method also effectively realizes this goal of education (Burnett, et al., 2005).

\section{Conclusion}

The paper concludes that despite of being criticized as an expensive and time consuming teaching and learning method, service-learning still occupies the position of a popular pedagogical critical strategy today. Many scholars have acknowledged that it effectively serves the citizenship and community development goals of education. Students who participate in service-learning have deeper sense of responsibility and develop awareness towards their community roles as active citizens. Service-learning is also acknowledged to be different from other community interventions such as community service, volunteerism and philanthropic works. It has been termed a reciprocal method that benefits both, the community as well as students. Students find community as a laboratory for learning and community find services in turn from students.

\section{Future Research}

This study explored extensive literature on the role of service-learning in developing students' citizenship and community awareness. Much work remains to be done in this area. For this purpose, it is recommended that future research must investigate into the factors which affect the service-learning setting, assessment of service-learning and its sustainability as a critical pedagogy in the era of technology.

\section{References}

Arenas, A., Bosworth, K., \& Kwandayi, H. P. (2006). Civic service through schools: An international perspective. Compare, 36(1), 23-40. Arman, J. F., \& Scherer, D. (2002). Service learning in school counselor preparation: A qualitative analysis. The Journal of Humanistic Counseling, Education and Development, 41(1), 69-86.

Astin, A. W., \& Sax, L. J. (1998). How undergraduates are affected by service participation. Journal of College Student Development, 
39(3), 251-263.

Baggerly, J. (2006). Service learning with children affected by poverty: Facilitating multicultural competence in counseling education students. Journal of Multicultural Counseling and Development, 34(4), 244-255.

Bandura, A., \& Adams, N. E. (1977). Analysis of self-efficacy theory of behavioral change. Cognitive Therapy and Research, 1(4), 287310.

Battistoni, R. M. (2002). Civic engagement across the curriculum: A resource book for service-learning faculty in all disciplines. Boston: Campus Compact.

Bazemore, G., \& Stinchcomb, J. (2004). Civic engagement model of reentry: Involving community through service and restorative justice. Federal Probation, 68(2), 14-24.

Brandell, M. E., \& Hinck, S. (1997). Service learning: Connecting citizenship with the classroom. NASSP Bulletin, 81(591), 49-56.

Bringle, R. G., \& Hatcher, J. A. (1995). A service-learning curriculum for faculty. Michigan Journal of Community Service Learning, 2(1), $112-122$.

Bringle, R. G., \& Hatcher, J. A. (1996). Implementing service learning in higher education. The Journal of Higher Education, 67(2), 221239.

Bringle, R. G., \& Hatcher, J. A. (2009). Innovative practices in service-learning and curricular engagement. New Directions for Higher Education, 2009(147), 37-46.

Bringle, R. G., \& Steinberg, K. (2010). Educating for informed community involvement. American Journal of Community Psychology, 46(3-4), 428-441.

Brown, L. H., \& Roodin, P. A. (2001). Service-learning in gerontology: An out-of-classroom experience. Educational Gerontology, 27(1), 89-103.

Burnett, J. A., Long, L. L., \& Horne, H. L. (2005). Service learning for counselors: Integrating education, training, and the community. The Journal of Humanistic Counseling, Education and Development, 44(2), 158-167.

Butin, D. W. (2006). The limits of service-learning in higher education. The Review of Higher Education, 29(4), 473-498.

Chickering, A., \& Braskamp, L. A. (2009). Developing a global perspective for personal and social responsibility. Peer Review, 11(4), 2730.

Cole, M., John-Steiner, V., Scribner, S., \& Souberman, E. (1978). LS Vygotsky - Mind in society: The development of higher psychological processes. Cambridge, MA: Harvard University Press.

Cone, D., \& Harris, S. (1996). Service-learning practice: A theoretical framework. Michigan Journal of Community Service Learning, 3(1), 31-43.

Cone, N. (2009). Community-based service-learning as a source of personal self-efficacy: preparing preservice elementary teachers to teach science for diversity. School Science and Mathematics, 109(1), 20-30.

Cruz, N. I., \& Giles, D. (2000). Where's the community in service-learning research. Michigan Journal of Community Service Learning, $7(1), 28-34$.

Dale, P. A., \& Drake, T. M. (2005). Connecting academic and student affairs to enhance student learning and success. New Directions for Community Colleges, 2005(131), 51-64.

Deans, T. (1999). Service-Learning in two keys: Paulo Freire's critical pedagogy in relation to John Dewey's pragmatism. Michigan Journal of Community Service Learning, 6(1), 15-29.

Desmond, K. J., \& Stahl, S. A. (2011). Implementing service learning into human service education. Journal of Human Services, 31(1), 5-16.

Diambra, J. F., McClam, T., Fuss, A., Burton, B., \& Fudge, D. L. (2009). Using a focus group to analyze students' perceptions of a service-learning project. College Student Journal, 43(1), 114-122.

Egger, J. B. (2008). No service to learning:"Service-learning" reappraised. Academic Questions, 21(2), 183-194.

Einfeld, A., \& Collins, D. (2008). The relationships between service-learning, social justice, multicultural competence, and civic engagement. Journal of College Student Development, 49(2), 95-109.

Engberg, M. E., \& Fox, K. (2011). Exploring the relationship between undergraduate service-learning experiences and global perspective-taking. Journal of Student Affairs Research and Practice, 48(1), 83-103.

Ethridge, E. A., \& Branscomb, K. R. (2009). Learning through action: Parallel learning processes in children and adults. Teaching and Teacher Education, 25(3), 400-408.

Eyler, J. (2002). Reflection: Linking service and learning -Linking students and communities. Journal of Social Issues, 58(3), 517-534.

Eyler, J., \& Giles Jr, D. E. (1999). Where's the learning in service-learning? San Francisco, CA: Jossey-Bass.

Fenzel, L. M., \& Peyrot, M. (2005). Comparing college community participation and future service behaviors and attitudes. Michigan Journal of Community Service Learning, 12(1), 23-31.

Fiske, E. B. (2002). Learning in deed: The power of service-learning for American schools. Battle Creek, MI: W.K. Kellogg Foundation.

Furco, A. (1996). Service-learning: A balanced approach to experiential education. In B. Taylor (Ed.), Expanding boundaries: Serving and learning (pp. 2-6). Washington, DC: Corporation for National Service.

Furco, A., \& Root, S. (2010). Research demonstrates the value of service learning. Phi Delta Kappan, 91(5), 16-20.

Giles, D. E., \& Eyler, J. (1994). The theoretical roots of service-learning in John Dewey: Toward a theory of service-learning. Michigan Journal of Community Service Learning, 1(1), 77-85.

Gottlieb, K., \& Robinson, G.(Eds) (2006). A practical guide for integrating civic responsibility into the curriculum (2nd ed.).. Washington, DC: Community College Press. 
Govekar, M. A., \& Rishi, M. (2007). Service learning: Bringing real-world education into the B-school classroom. Journal of Education for Business, 83(1), 3-10.

Hager, P., Holland, S., \& Beckett, D. (2002). Enhancing the learning and employability of graduates: The role of generic skills. Business Higher Education Round Table Paper Discussion No. 9.

Haski-Leventhal, D., Gronlund, H., Holmes, K., Meijs, L. C., Cnaan, R. A., Handy, F., \& et al. (2010). Service-learning: Findings from a 14-nation study. Journal of Nonprofit \& Public Sector Marketing, 22(3), 161-179.

Hondagneu-Sotelo, P., \& Raskoff, S. (1994). Community service-learning: Promises and problems. Teaching Sociology, 22(3), $248-254$.

Howard, J. (2003). Service-learning research: Foundational issues. In S.H. Billig \& A. S. Water-man (Eds), Studying service-learning: Innovations in education research methodology (pp. 1-12). Mahwah, NJ: Erlbaum.

Howard, J. P. (1998). Academic service learning: A counternormative pedagogy. New Directions for Teaching and Learning, 73(Spring), 21-29.

Kahne, J., Westheimer, J., \& Rogers, B. (2000). Service-learning and citizenship: Directions for Research. Michigan Journal of Community Service Learning, Special Issue(1), 42-51.

Kaye, C. B. (2004). The complete guide to service learning: Proven, practical ways to engage students in civic responsibility, academic curriculum \& social action. Minneapollis, MN: Free Spirit Pub.

Keen, C., \& Hall, K. (2009). Engaging with difference matters: Longitudinal student outcomes of co-curricular service-learning programs. The Journal of Higher Education, 80(1), 59-79.

Kenworthy-U'Ren, A. L., \& Peterson, T. O. (2005). Service-learning and management education: Introducing the "We Care" approach. Academy of Management Learning \& Education, 4(3), 272-277.

Kezar, A., \& Rhoads, R. A. (2001). The dynamic tensions of service learning in higher education: A philosophical perspective. Journal of Higher Education, 72(2), 148-171.

Kielsmeier, J. C., Scales, P. C., Roehlkepartain, E. C., \& Neal, M. (2004). Community service and service-learning in public schools. Reclaiming children and youth, 13, 138-143.

King, J. T. (2004). Service-learning as a site for critical pedagogy: A case of collaboration, caring, and defamiliarization across borders. Journal of Experiential Education, 26(3), 121-137.

Kolb, D. A. (1984). Experiential learning: Experience as the source of learning and development. Englewood Cliffs, NJ: Prentice-Hall.

Lane, S. (2008). Benefits of service learning. Reason and Respect, 3(2), 6-7.

Lawrence, M. N., \& Butler, M. B. (2010). Becoming aware of the challenges of helping students learn: An examination of the nature of learning during a service-learning experience. Teacher Education Quarterly, 155-175.

Lemieux, C. M., \& Allen, P. D. (2007). Service learning in social work education: The state of knowledge, pedagogical practicalities, and practice conundrums. Journal of Social Work Education, 43(2), 309-326.

Markus, G. B., Howard, J. P., \& King, D. C. (1993). Notes: Integrating community service and classroom instruction enhances learning: Results from an experiment. Educational Evaluation and Policy Analysis, 15(4), 410-419.

Maybach, C. W. (1996). Investigating urban community needs: Service learning from a social justice perspective. Education and Urban Society, 28(2), 224-236.

McClam, T., Diambra, J. F., Burton, B., Fuss, A., \& Fudge, D. L. (2008). An analysis of a service-learning project: Students' expectations, concerns, and reflections. Journal of Experiential Education, 30(3), 236-249.

Metcalf, L. E. (2010). Creating international community service learning experiences in a capstone marketing-projects course. Journal of Marketing Education, 32(2), 155-171.

Moore, D. T. (2000). The Relationship between Experiential Learning Research and Service-Learning Research. Michigan Journal of Community Service Learning, Special Issue, 124-128.

Morgan, W., \& Streb, M. (2001). Building citizenship: How student voice in service-learning develops civic values. Social Science Quarterly, 82(1), 154-169.

Myers-Lipton, S. J. (1996). Effect of a comprehensive service-learning program on college students' level of modern racism. Michigan Journal of Community Service Learning, 3(1), 47-54.

Ottenritter, N. W. (2004). Service learning, social justice, and campus health. Journal of American College Health, 52(4), $189-192$.

Parker, B., \& Altman Dautoff, D. (2007). Service-learning and study abroad: Synergistic learning opportunities. Michigan Journal of Community Service Learning, 13(2), 40-53.

Prentice, M. (2011). Civic engagement among community college students through service learning. Community College Journal of Research and Practice, 35(11), 842-854.

Pritchard, F. F., \& Whitehead III, G. I. (2004). Serve and learn: Implementing and evaluating service-learning in middle and high schools. Mahwah, NJ: Routledge.

Quezada, R. L., \& Christopherson, R. W. (2005). Adventure-based service learning: University students' self-reflection accounts of service with children. Journal of Experiential Education, 28(1), 1-16.

Rama, D. V., Ravenscroft, S. P., Wolcott, S. K., \& Zlotkowski, E. (2000). Service-learning outcomes: Guidelines for educators and researchers. Issues in Accounting Education, 15(4), 657-692.

Ramaley, J. A. (2000). Strategic directions for service-learning research: A presidential perspective. Michigan Journal of Community Service Learning, Special Issue(1), 91-97.

Redman, R. W., \& Clark, L. (2002). Service-learning as a model for integrating social justice in the nursing curriculum. Journal of Nursing Education, 41(10), 446-449. 
Reinke, S. J. (2003). Making a difference: Does service-learning promote civic engagement in MPA students? Journal of Public Affairs Education, 9(2), 129-138.

Reising, D. L., Shea, R. A., Allen, P. N., Laux, M. M., Hensel, D., \& Watts, P. A. (2008). Using service-learning to develop health promotion and research skills in nursing students. International Journal of Nursing Education Scholarship, 5(1), 1-15.

Root, S., Callahan, J., \& Sepanski, J. (2002). Building Teaching Dispositions and Service-Learning Practice: A Multi-Site Study. Michigan Journal of Community Service Learning, 8(2), 50-60.

Ryan, M. (2012). Service-learning after learn and serve America: How five states are moving forward. Education Commission of the States, Denver, CO.

Saltmarsh, J. (1996). Education for critical citizenship: John Dewey's contribution to the pedagogy of community service learning. Michigan Journal of Community Service Learning, 3(1), 13-21.

Saltmarsh, J. (2005). The civic promise of service learning. Liberal Education, 91(2), 50-55.

Sax, L. J. (2004). Citizenship development and the American college student. New Directions for Institutional Research, 2004(122), 6580.

Schwartzman, R. (2007). Service-Learning Pathologies and Prognoses. Journal of Community Engagement, 1(2), 1-17.

Sedlak, C. A., Doheny, M. O., Panthofer, N., \& Anaya, E. (2003). Critical thinking in students' service-learning experiences. College Teaching, 51(3), 99-104.

Seifer, S. D. (1998). Service-learning: Community-campus partnerships for health professions education. Academic Medicine, 73(3), 273-277.

Sheu, L. C., Zheng, P., Coelho, A. D., Lin, L. D., O'Sullivan, P. S., O’Brien, B. C., Yu, A.Y., \& Lai, C. J. (2011). Learning through service: Student perceptions on volunteering at interprofessional hepatitis B student-run clinics. Journal of Cancer Education, 26(2), 228233.

Simons, L., \& Cleary, B. (2006). The influence of service learning on students' personal and social development. College Teaching, 54(4), 307-319.

Skinner, R., \& Chapman, C. (1999). Service-Learning and Community Service in K-12 Public Schools. National Center for Education Statistics: Statistics in Brief (NCES 1999-043).

Speck, B. W. (2001). Why service-learning? New Directions for Higher Education, 2001(114), 3-13.

Speck, B. W., \& Hoppe, S. L. (2004). Service-learning: History, theory, and issues: Greenwood Publishing Group.

Steinberg, K. S., Hatcher, J. A., \& Bringle, R. S. (2011). Civic-minded graduate: A north star. Michigan Journal of Community Service Learning, 18(1), 19-33.

Strupeck, C. D., \& Whitten, D. (2004). Accounting service-learning experiences and the IRS volunteer income tax assistance programme: A teaching note. Accounting Education, 13(1), 101-112.

Teranishi, C. S. (2007). Impact of experiential learning on Latino college students' identity, relationships, and connectedness to community. Journal of Hispanic Higher Education, 6(1), 52-72.

Terkla, D. G., O'Leary, L. S., Wilson, N. E., \& Diaz, A. (2007). Civic engagement assessment: Linking activities to attitudes. Assessment Update, 19(4), 1-2.

Tryon, E., Stoecker, R., Martin, A., Seblonka, K., Hilgendorf, A., \& Nellis, M. (2008). The challenge of short-term service-learning. Michigan Journal of Community Service Learning, 14(2), 16-26.

Tucker, M. L., McCarthy, A. M., Hoxmeier, J. A., \& Lenk, M. M. (1998). Community service learning increases communication skills across the business curriculum. Business Communication Quarterly, 61(2), 88-99.

Vogelgesang, L. J., \& Astin, A. W. (2000). Comparing the effects of community service and service-learning. Michigan Journal of Community Service Learning, 7(1), 25-34.

Wade, R., \& Yarbrough, D. (2007). Service-learning in the social studies: Civic outcomes of the 3rd-12th grade CiviConnections program. Theory and Research in Social Education, 35(3), 366-392.

Waldstein, F. A., \& Reiher, T. C. (2001). Service-learning and students' personal and civic development. Journal of Experiential Education, 24(1), 7-13.

Wells, C. V., \& Grabert, C. (2004). Service-learning and mentoring: Effective pedagogical strategies. College Student Journal, 38(4), 573-578.

Yorio, P. L, \& Ye, F. (2011). A meta-analysis on the effects of service-learning on the social, personal, and cognitive outcomes of learning. Academy of Management Learning \& Education, 11(1), 9-27.

Zaff, J. F., \& Lerner, R. M. (2010). Service learning promotes positive youth development in high school. Phi Delta Kappan, 91(5), $21-23$.

Zimmerman, B. J., \& Cleary, T. J. (2006). Adolescents' development of personal agency: The role of self-efficacy beliefs and selfregulatory skill. In F. Pajares and T. Urdan (Eds), Self-efficacy beliefs of adolescents (pp. 45-69). Greenwich, CT: Information Age Publishing.

Zlotkowski, E. (1995). Does service-learning have a future? Michigan Journal of Community Service Learning, 2(1), 123-133. 